\title{
Rhodium-Catalyzed Asymmetric C-H Functionalization of Methyl Ethers
}

\section{Key words}

\section{rhodium}

C-H functionalization

General reaction:

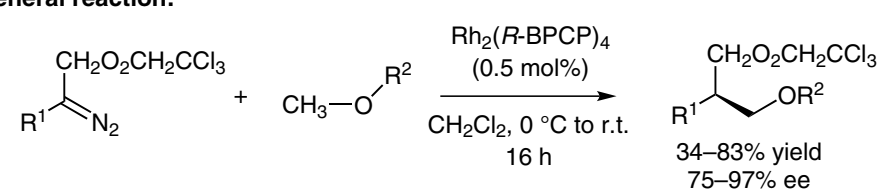

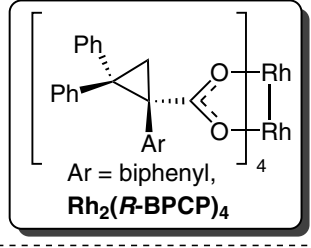

Selected examples:<smiles>CC(COC(C)(C)C)c1ccc(Br)cc1</smiles>

$83 \%$ yield, $91 \%$ ee<smiles>CCOC(=O)CC(COC(C)(C)C)c1ccc(Br)cc1</smiles>
(gram scale: $95 \%, 90 \%$ ee)<smiles>CC(COC(C)(C)C)c1ccc(C(C)(C)C)cc1</smiles>

$77 \%$ yield, $97 \%$ ee<smiles>CC(COC(C)(C)C)c1ccc(F)cc1</smiles><smiles>CC(/C=C/c1cc([14CH3])c(Cl)c(Cl)c1)COC(C)(C)C</smiles>

$61 \%$ yield, $99 \%$ ee<smiles>COCC(=O)OCC(COCCCl)c1ccc(Br)cc1</smiles>

$\mathrm{Br}^{2}$

$58 \%$ yield, $93 \%$<smiles>CC(COC(C)(C)C)c1ccc(C(F)(F)F)cc1</smiles>

$80 \%$ yield, $98 \%$ ee<smiles>Cc1cc(C(COC(=O)OCc2ccccc2)COC(C)(C)C)on1</smiles>

$34 \%$ yield, $75 \%$ ee

Accessing different diastereomers utilizing a chiral menthol substrate:

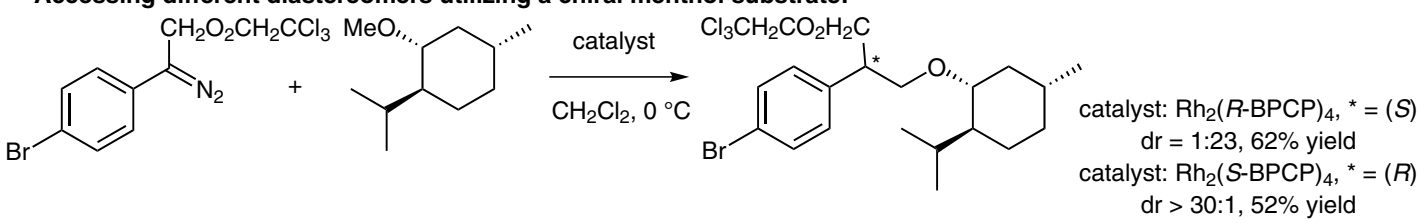

Significance: The asymmetric site-selective functionalization of unactivated $\mathrm{sp}^{3} \mathrm{C}-\mathrm{H}$ bonds is one of the most challenging reactions to date. Davies and co-workers demonstrated in this article the utility of trichloroethyl aryldiazoacetates as excellent substrates in the Rh-catalyzed enantioselective functionalization of methyl ethers.

sYNFACTS Contributors: Mark Lautens, Charles C. J. Loh Synfacts 2015, 11(3), $0271 \quad$ Published online: 16.02.2015 Dol: 10.1055/s-0034-1380095; Reg-No.: L01515SF
Comment: A wide spectrum of methyl ethers can be functionalized with trichloroethyl aryldiazoacetates with moderate and good yields and excellent enantioselectivities. In all cases, regioselectivity of the carbene insertion is on the less hindered methyl moiety. When a chiral ether was utilized, different diastereomeric products could be selectively accessed using opposite enantiomers of the chiral catalyst (matched and mismatched). 